\title{
Countries closing down - Reproducibility keeping science open
}

Karsten Boye Rasmussen

Welcome to volume 44 of the IASSIST Quarterly. Here in 2020 we start with a double issue on reproducibility (IQ 44(1-2)).

The start of 2020 was in the sign of Corona. Though we are now only in the middle of the year, we can say with confidence that 2020 will be known for the closing down of nearly all public life. From our very own world this included the move of the IASSIST 2020 conference to 2021 . The closing down of societies took different forms and this will and should be long debated and investigated, because many civil rights in open society were put on instant standby by governments, with various precautionary measures. Fortunately, many countries are now in the processes of opening up. Hopefully, we are now more careful, keeping socially distant, executing better sanitation, etc. We are also eagerly expectant of science breakthroughs: the vaccine, the better treatment, the cure. But Corona science extends beyond health and biology. Social science in particular has an obligation to make us better prepared to take necessary measures and to uphold democracy.

Social science will always have the problem of reliability that you cannot step into the same river twice: Survey data collected at one time will not in a subsequent data collection bring the same results, even with the same panel of respondents. Reproducibility has many more forms than exact data collection, though, and is foundational for open science and an open society. Science needs to be transparent in order to be challenged and improved. Fellow scientists as well as laymen should have the possibility of performing analyses to find whether results can be reproduced.

I am therefore very happy to send my thanks to Harrison Dekker and Amy Riegelman for taking the initiative to create this special issue of the IASSIST Quarterly on reproducibility. Harrison Dekker is a data librarian at University of Rhode Island and Amy Riegelman a librarian in social sciences at the University of Minnesota. Together, Amy and Harrison reviewed the papers submitted for their special issue and wrote the introduction in the following pages. In addition to expressing my great appreciation to them, I also want to thank all the authors who submitted papers for this issue.

Thanks! Let's keep science open again!

Submissions of papers for the IASSIST Quarterly are always very welcome. We welcome input from IASSIST conferences or other conferences and workshops, from local presentations or papers especially written for the $I Q$. When you are preparing such a presentation, give a thought to turning your one-time presentation into a lasting contribution. Doing that after the event also gives you the opportunity of improving your work after feedback. We encourage you to login or create an author login to https://www.iassistquarterly.com (our Open Journal System application). We permit authors 'deep links' into the $I Q$ as well as deposition of the paper in your local repository. Chairing a conference session with the purpose of aggregating and integrating papers for a special issue $I Q$ is also much appreciated as the information reaches many more people than the limited number of session participants and will be readily available on the IASSIST Quarterly website at 
https://www.iassistquarterly.com. Authors are very welcome to take a look at the instructions and layout:

https://www.iassistquarterly.com/index.php/iassist/about/submissions

Authors can also contact me directly via e-mail: kbr@sam.sdu.dk. Should you be interested in compiling a special issue for the $I Q$ as guest editor(s) I will also be delighted to hear from you.

Karsten Boye Rasmussen - June 2020 